\title{
Özel Spor Merkezlerine Üye Olan Bireylerin Spora Yönelme Nedenleri ve Beklentilerinin Gerçekleşme Düzeyleri
}

\author{
DOI: 10.26466/opus.549924 \\ * \\ Nevzan Şelale Akça * - Hakan Sunay **
}

*Uzm, Ankara Üniversitesi, Spor Bilimleri Fak., Spor Yöneticiliği Böl., Gölbaşı/Ankara/Türkiye

E-Posta: selale.akca@yahoo.com

ORCID: $\quad$ 0000-0003-0434-7610

* *Doç. Dr. Ankara Üniversitesi, Spor Bilimleri Fak., Spor Yöneticiliği Böl., Gölbaşı/Ankara/Türkiye E-Posta: hsunay@ankara.edu.tr

ORCID: $\underline{0000-0001-5139-1492}$

Öz

Günümüzde spor, ekonomik kazanç sağlayan, ülkeler arasında rekabeti artıran ve dünyada farkl kültür ve sosyal statülerden insanlarn bir araya gelerek birlikte tüketebildiği ortak bir üründür. Boş zamanımı spor yaparak değerlendiren bireylerin daha sağlıkl, hareketli ve daha bilinçli olduğu bilindiğine göre sporun yaygınlaştırılması genel toplum să̆lığının dolayıst ile genel nüfusun içersinde sağlıklı insan sayısının artmasını să̆layacaktır. Sağlıklı yaşam için sporun kitlelere yaygıılaşıtırlması ve geliştirilmesinde en etkili yollardan biri de özel spor merkezleridir. Çalışma; Ankara'daki özel spor merkezlerine üye olan bireylerin spora yönelme nedenleri ile beklentilerini ve bu beklentilerin gerçekleşme düzeylerini belirlemeye yönelik yapılmıştır. Araştırmanın evreni, 15 adet özel spor merkezine üye olan toplamda 24.500 kişiden oluşmaktadır. Araştırma örneklemi bu merkezlere üye olan ve araştırmaya gönüllü katılan 658 kişiden oluşmuştur. Veriler araştırmacılar tarafindan geliştirilen anket yoluyla toplanmıştır. Anketlerden elde edilen verilerin yüzde ve frekans dağılımları çıkarılmış, değişkenler arasındaki ilişkinin belirlenmesinde Ki-kare testi kullanılmıştır. Anketin Cronbach Alfa değeri ( $\alpha$ ) 74,6'dır. Özel spor merkezlerine üye olan bireylerin spor merkezlerine gelmedeki amaçlarının yaş grupları, cinsiyet, eğitim ve ekonomik durum özelliklerinde benzerlikler taşıdığı belirlenmiştir. Üyelerin beklentileri sağllklı olmak, hareket etmek, stres atmak ve zayıflamak yönündedir. Sonuç olarak, Bireylerin spor merkezlerine yönlendirilmelerinde arkadaş ve ikametgâh yeri faktörünün ă̆ırlıkta olduğu, aile, işyeri ve okul faktörünün ise ă̆ırliklı etkiye sahip olmadı̆̆ belirlenmiştir. Araştırmaya katılanların özel spor merkezlerinden bekledikleri; sağlıkl olmak, form tutmak, zayıflamak, stres atmak, hareket etmek ve yeni deneyimler kazanmak beklentilerini karşılanmazken, öz saygı kazanmak ve yeni insanlar tanıma beklentileri karşılanmışıı.

Anahtar Kelimeler: Spor merkezi, Spora yönelme nedenleri, Spordan beklentiler 


\title{
Reasons and Satisfaction Rate of Expectations of the Individuals Who Are Members of Private Sport Centers
}

\begin{abstract}
Today, sport is a common product that provides economic gain, increases competition among countries, and allows people from different cultural and social backgrounds to come together and consume them together all over the world. Since it is known that the individuals who evaluate leisure time by sport are healthier, more mobile and more conscious, dissemination of sports will increase the number of healthy people in the general population because of general society health. One of the most effective ways to promote and promote sports for the wellness of the masses is the private sports centers. This study was carried out to investigate the causes of individuals who are members of private sports centers in Ankara and to orient them towards more spores. The universe of the study is composed of 24,500 people who are members of 15 private sports centers. The research sample consisted of 658 persons who were members of the centers and voluntarily participated in the research. The research data were collected through a questionnaire developed by the researchers. Percentage and frequency distributions of the data obtained from the questionnaires. The Cronbach Alpha value ( $\alpha$ ) of the questionnaire is 74, 6 for the 30 questions. It is revealed that the aims and preferences for coming to sports centers have similarities in age groups, gender, education and economic situation characteristics in order to determine the expectations of the members who are members of special sports centers. The expectations of the members are mostly to be healthy, to move, to stress and to weaken. As a result, it has been determined that the family factor, the workplace and the school factor do not have a significant effect on the individuals participating in the study. Individuals involved in the research are expected to acquire self-esteem and recognize new people while they are not expected to be healthy, to form, to weaken, to stress, and to act and gain new experiences that are expected from private sports centers.
\end{abstract}

Keywords: Sport center, Reasons to do sport, Expectations on sport 


\section{Giriş}

Hızla ilerleyen günümüz teknolojisi ve teknolojik ürünleri içeren araç gereç ve makineler, insanların hareketliliğini sınırlamış ve beraberinde insanın doğasına uymayan bir yaşam biçimini getirmiştir. Bunun sonucunda insanlar hareketsiz, hasta ve mutsuz bireylere dönüşmüşlerdir. $\mathrm{Bu}$ tür olumsuzlukların tedavisinde ise spor bir tedavi aracı olarak kullanılmaya başlanmıştır. Günümüzde spor ve insan yaşamı birbirinden ayrılmaz hale gelmiştir. Bu nedenle hangi yaşta olursa olsun, bilimsel temellere dayalı, bilinçli ve sistemli yapılan spor, insanın tüm yaşamı boyunca sağlıklı, uyumlu, başarılı, mutlu olmasında ve normal gücün yüksek tutulmasında önemli bir rol oynamaktadır (Amman, 2005). Spor yapmanın temel amacl; hareketsiz bir yaşantının neden olduğu organik, psikolojik ve fiziki bozuklukları önlemek veya yavaşlatmak beden sağlığının temeli olan fizyolojik kapasiteyi yükseltmek, fiziksel uygunluğu ve sağlı̆̆ uzun yıllar muhafaza etmektir.

1982 Anayasasının 59. maddesinde her yaştaki vatandaşlar için beden eğitiminin sağlanması devletin görevi olarak belirtilmiştir. Bundan dolayı " Kitle sporu "," Yaşam boyu spor "," Herkes için spor " ve " Sağlıklı yaşam için spor " gibi sloganlarla, farklı cins, meslek ve statüdeki bireyleri aktif olarak spora çekebilme adına bu bireylerin boş zaman faaliyetlerinde spor yapma eğilimleri teşvik edilmiştir (Fişek,1998). Günümüzde spor, ekonomik kazanç sağlayan, ülkeler arasında rekabeti artıran ve tüm dünyada farklı kültür ve sosyal statülerden insanların bir araya gelerek birlikte tüketebildiği ortak bir üründür. Boş zamanını spor yaparak değerlendiren bireylerin daha sağlıklı, daha hareketli ve daha bilinçli olduğu bilindiğine göre sporun yaygınlaştırılması genel toplum sağlığının dolayısı ile genel nüfusun içersinde sağlıklı insan sayısının artmasını sağlayacaktır (Brown ve Frankel,1993).

Günümüzde spor, kişisel ve toplumsal sağlığ1 koruyucu ve geliştirici nitelikleriyle önemli bir hizmet sektörü olarak kabul görmektedir. Bu nedenle spor aktivitelerine ve organizasyonlarına verilen önem giderek artmaktadır. Bu çalışmanın amacı, sağlıklı, sosyal ve kültürel alanda çağdaş bir toplum yaratmada toplum bireylerinin spor yapmasının öneminden hareketle Ankara'da özel spor merkezlerine üye olan bireylerin spora yönelme nedenlerini ve beklentilerini araştırmaktır. 


\section{Yöntem}

\section{Araştırmanın modeli}

Araştırmada nicel araştırma tekniklerinden betimsel yöntem kullanılmıştır. Betimsel yöntem, var olan durumu ortaya koyan bir durum saptamasıdır (Kaptan,1998). Ankara'da Spor Genel Müdürlüğü (SGM) verilerine göre 33 adet küçük ve büyük ölçekli vücut geliştirme ve sağlıklı yaşam merkezi bulunmaktadır.

\section{Araştırmanın çalışma evreni}

2014 yılında Ankara ilinde bulunan, bünyesinde vücut geliştirme salonlarının yanı sıra çeşitli spor branşlarını bulunduran ve üye sayısı 500'ün üzerinde olan 15 adet (Base Life Club, Oranium Sports Club, Sports International, Ankara Üniversitesi Olimpik Yüzme Havuzu, Joya Life, Sporthill Incek, Sportif Yaşam Kulübü, Ankyra Spor ve Yaşam Kulübü, United Clubs Konutkent, ENNfit Family Club, Dolphin Să̆lıklı Yaşam Kulübü, Delos Sport $\mathcal{E}$ Squash Club, Pelops Sports Club, SportsA Life Club, Sporty Spor ve Sağliklı Yaşam Kulübü) özel spor merkezidir. Araştırmanın evreni; 15 adet özel spor merkezine üye olan toplamda yaklaşık 24.500 kişiden oluşmaktadır.

\section{Araştırma örneklemi}

Söz konusu merkezlere üye olan ve araştırmaya gönüllü katılan 658 kişiden oluşmuştur. Çalışmada basit tesadüfi örnekleme yöntemi kullanılmıştır. Evren bütünlüğüne göre örneklem hesabında gerekli formüllerden yararlanılmış ve örneklem sayısının araştırma için uygun olduğuna karar verilmiştir (Balc1,2015).

\section{Veri toplama arac1}

Araştırmada veri toplama aracı olarak anket formu kullanılmıştır. Anket formu kişisel bilgiler ve beklentileri belirlemeye yönelik 36 sorudan oluşmaktadır. Çalışmada kullanılan anketin 1. bölümünde ise spor tesisini kullanan bireylerin yaş, cinsiyet, eğitim durumları, meslekleri ve 
gelir seviyeleri gibi demografik faktörlerin neler olduğu, bu faktörlerin sonuca ne şekilde tesir ettiğini öğrenebilmek için hazırlanmıştır. Anketin 2. bölümünde ise toplam 30 soru 5'li likert tipinde kullanılarak hazırlanmıştır. Spor merkezine üye olanlar beklentilerini 5 etki düzeyinde değerlendirmişlerdir. 5'li Likert tipinde hazırlanan anketin etki düzeyleri; 1-1,80 arası (Hiç), 1,81-2,60 arası (Az), 2,61-3,40 arası (Orta), 3,41-4,20 arası (Çok), 4,21-5,00 arası ise (Tam) olarak belirlenmiş, elde edilen beklenti düzeyleri ortalamaları ise bu aralıklara göre yorumlanmıştır. Bu bolümdeki amaç, özel spor merkezini kullanan bireylerin spora yönelmelerini etkileyen faktörlerin ne olduğu, spordan beklentileri ve bu beklentilerin gerçekleşme düzeylerini ne ölçüde etkilediğini tespit edebilmek amacıyla hazırlanmıştır.

\section{Verilerin analizi}

Toplanan verilerin analizi için istatistiksel işlemler olarak anketin değerlendirilmesi SPSS 16 paket programında frekans ve yüzde (\%) dağılımı ile ilişkilendirmelerde ki-kare analizleri yapılmış, istatistiksel anlamlılık için alpha değeri 0,05 kabul edilmiştir. Anketin 5'li likert ile hazırlanan 30 soruluk kısmı için Cronbach Alfa değeri $(\alpha)$ 74,6'dır. Verilerin açıklayıcı faktör analizi için uygunluğu Kaiser- Meyer- Olkin (KMO) katsayısı ve Barlett Sphericity testi ile incelenmiştir. KMO değeri (.838); bu örnekteki 658 kişilik örneklem büyüklüğünün yeterli olduğunu ve Bartlett's testi sonuçları da $(\mathrm{p}<.01)$ verilerin normal dağılıma sahip olduğunu göstermektedir. KMO'nun .60 'dan yüksek, Barlett testinin anlamlı çıkması verilerin faktör analizi için uygun olduğunu gösterir (Büyüköztürk, 2018). Ankette yer alan maddeler bir faktörde toplanmakta ve maddelerin faktör yükleri 75-57 arasında değişmektedir. Madde toplam korelasyonları da maddelerin ayırt edici güçlerinin yüksek olduğunu göstermektedir. Madde toplam korelasyonları da 72-52 arasında değişmektedir. Buna göre anket maddelerinin her birinin ayırt ediciliğinin yüksek olduğu söylenebilir. Ankete madde-toplam korelasyonları katsayısı 0.52 'den yüksek olan 30 madde dâhil edilmiştir. 


\section{Bulgular}

Araştırmaya katılan bireylerin kişisel bilgilerine göre dağılımları Tablo 1 'de verilmiştir.

Tablo 1. Üyelerin kişisel bilgilerinin genel dağılımları ve yüzdeleri

\begin{tabular}{|c|c|c|}
\hline Yaş & $\mathbf{N}$ & $\%$ \\
\hline $18-25$ & 129 & 19,6 \\
\hline $26-40$ & 130 & 19,8 \\
\hline $41-65$ & 399 & 60,6 \\
\hline Toplam & 658 & 100,0 \\
\hline Cinsiyet & $\mathbf{N}$ & $\%$ \\
\hline Kadın & 394 & 60,0 \\
\hline Erkek & 264 & 40,0 \\
\hline Toplam & 658 & 100,0 \\
\hline Meslek & $\mathbf{N}$ & $\%$ \\
\hline Öğrenci & 130 & 19,8 \\
\hline Memur & 93 & 14,1 \\
\hline İşçi & 94 & 14,3 \\
\hline Serbest Meslek & 161 & 24,5 \\
\hline Çalışmıyor & 37 & 5,6 \\
\hline Emekli & 143 & 21,7 \\
\hline Toplam & 658 & 100,0 \\
\hline Eğitim Düzeyi & $\mathbf{N}$ & $\%$ \\
\hline İlköğretim & 2 & 0,3 \\
\hline Lise & 68 & 10,3 \\
\hline Lisans & 486 & 73,9 \\
\hline Lisansüstü & 102 & 15,5 \\
\hline Toplam & 658 & 100,0 \\
\hline Gelir Düzeyi & $\mathbf{N}$ & $\%$ \\
\hline $1000-2500$ & 251 & 38,1 \\
\hline $2501-4000$ & 203 & 30,9 \\
\hline $4001-5000$ & 117 & 17,8 \\
\hline 5001-üstü & 87 & 13,2 \\
\hline Toplam & 658 & 100,0 \\
\hline Üyelik Süresi & $\mathbf{N}$ & $\%$ \\
\hline 1 yıldan az & 259 & 39,4 \\
\hline $1-3$ & 224 & 34,0 \\
\hline $4-6$ & 106 & 16,1 \\
\hline 6 yıldan fazla & 69 & 10,5 \\
\hline Toplam & 658 & 100,0 \\
\hline
\end{tabular}


Araştırmaya katılan üyelerin çoğunluğu; 41-65 yaş grubundan $(60,6)$, $\% 60,0$ '1 kadın, \%24,5'i serbest meslek grubundan, \%73,9'u lisans eğitimi görmüştür. Gelir düzeyi olarak çoğunluk 4001-5000 TL üzeri gelir grubuna sahiptir. Üyelik süresi ise çoğunlukla 4-6 y1l üyeliği olan gruptur. Spora yönelten faktörlerin özel spor merkezi üyesi bireyler üzerindeki etki düzeylerinin dağılımı Tablo 2'de belirtilmiştir.

Tablo 2. Spora yönelten faktörlerin bireyler üzerindeki etki düzeyleri

\begin{tabular}{|c|c|c|c|c|c|c|}
\hline \multirow{3}{*}{$\begin{array}{ll}\text { Spora } & \text { yönelten } \\
\text { faktörler } & \end{array}$} & Hiç & $\mathbf{A z}$ & Orta & \multirow{3}{*}{$\begin{array}{l}\text { Çok } \\
\text { F } \\
\%\end{array}$} & Tam & \multirow{3}{*}{$\begin{array}{l}\text { Ortalama- } \\
x\end{array}$} \\
\hline & $\%$ & $\%$ & $\%$ & & F $\%$ & \\
\hline & & & & & & \\
\hline Aile & $256-38,9$ & $191-20,9$ & $123-18,7$ & $81-12,3$ & $7-1,1$ & $1,88-$ hiç \\
\hline Okul & $415-63,1$ & $132-20,1$ & $57-8,7$ & $45-6,8$ & $9-1,4$ & 1,63-hiç \\
\hline İşyeri & $427-64,9$ & $120-18,2$ & $74-11,2$ & $30-4,6$ & $7-1,1$ & 1,58-hiç \\
\hline Arkadaş & $94-14,3$ & $109-16,6$ & $193-29,3$ & $236-35,9$ & $26-4,0$ & 3,86-çok \\
\hline Doktor önerisi & $210-31,9$ & $142-21,6$ & $137-20,8$ & $98-14,9$ & $71-10,8$ & $2,41-\mathrm{az}$ \\
\hline Basın-yayın & $273-41,5$ & $119-18,1$ & $131-19,9$ & $116-17,6$ & $19-2,9$ & $2,07-a z$ \\
\hline Uzaklık yakınlık & $106-16,1$ & $140-21,3$ & $131-19,9$ & $204-31,0$ & $77-11,7$ & 3,63-çok \\
\hline $\begin{array}{l}\text { Diğer (Bireyin kendi } \\
\text { isteği ile) }\end{array}$ & $486-73,9$ & $0-0$ & $0-0$ & $62-9,4$ & $110-16,7$ & $1,98-\mathrm{az}$ \\
\hline
\end{tabular}

Tablo 2'de görüldüğü gibi, Spor yapmaya yönelten faktörlerden toplamda Bireyin kendi isteğinin \%73,9 (486 kişi), \%38,9'u (256 kişi) ailenin etkisinin, \%63,1 oranında (415 kişi) okul faktörünün \%64,9 oranında (427 kişi) ve işyeri faktörünün \%41,5 oranında (273 kişi) spora yönelten unsurlar arasında "hiç etkisinin olmadı̆̆ı" belirlenmiştir. Öte yandan Arkadaş faktörü \%35,9 (236 kişi) ile spor merkezlerine yakınlık durumu \%31,0 (204 kişi) "etki düzeyinin "Çok" olduğu görülmektedir.

Özel spor merkezi üyelerinin spordan beklenti düzeylerinin dağılımı Tablo 3'de belirtilmiştir.

Tablo 3'te özel spor merkezi üyelerinin yaptıkları spor branşından beklentilerinin tanımlayıcı istatistikleri yer almaktadır. Buna göre; Hareket etmek, formda olmak, stres atmak ve zayiflamak beklentilerinin yüzdelerine ve frekanslarına baktığımızda beklenti seviyelerinin "çok" olduğu söylenebilir. Yeni insanlar tanımak, benlik duygusunu geliştirmek, öz saygının artması ve yeni deneyimler kazanmak beklentileri frekans ve yüzdelerinden elde edilen verilere göre "az" se- 
viyededir. Sağliklı olmak ve boş zaman değerlendirme beklentileri ise yine aynı verilerden görülebileceği üzere "orta" seviyededir.

Tablo3. Özel Spor Merkezi Üyelerinin Spordan Beklenti Düzeylerinin Dağılımı

\begin{tabular}{|c|c|c|c|c|c|c|}
\hline Spordan Beklenti & Hiç & $\mathbf{A z}$ & Orta & Çok & Tam & Ort \\
\hline düzeyleri & $\%$ & $\%$ & $\%$ & $\begin{array}{l}\mathbf{F} \\
\%\end{array}$ & & $\mathrm{x}$ \\
\hline Hareket etmek & $9-1,4$ & $8-1,2$ & $98-14,9$ & $391-59,4$ & $152-23,1$ & 4,02 \\
\hline Sağlıklı olmak & $9-1,4$ & $3-0,5$ & $100-15,2$ & $326-49,5$ & $220-33,4$ & 2,70 \\
\hline Formda kalmak & $0-0$ & $9-1,4$ & $20-3,0$ & $422-64,1$ & $207-31,5$ & 4,26 \\
\hline Zayıflamak & $21-3,2$ & $22-3,3$ & $123-18,7$ & $338-51,4$ & $154-23,4$ & 3,88 \\
\hline Yeni insanlar tanımak & $126-9,1$ & $215-32,7$ & $178-27,1$ & $124-18,8$ & $15-2,3$ & 2,52 \\
\hline $\begin{array}{l}\text { Serbest zamanı değer- } \\
\text { lendirmek }\end{array}$ & $67-10,2$ & $99-17,0$ & $192-29,2$ & $267-40,6$ & $33-5,0$ & 3,15 \\
\hline Stres atmak & $94-14,3$ & $64-9,7$ & $102-15,5$ & $258-39,2$ & $140-21,3$ & 3,43 \\
\hline $\begin{array}{l}\text { Benlik duygusunu } \\
\text { geliştirmek }\end{array}$ & $231-35,1$ & $251-38,1$ & $94-14,3$ & $64-9,7$ & $18-2,7$ & 2,41 \\
\hline Öz saygı kazanmak & $210-31,9$ & $277-42,1$ & $115-17,5$ & $47-7,1$ & $9-1,4$ & 2,04 \\
\hline $\begin{array}{l}\text { Yeni deneyimler ka- } \\
\text { zanmak }\end{array}$ & $179-27,2$ & $149-22,6$ & $219-33,3$ & $64-9,7$ & $41-6,2$ & 2,42 \\
\hline Diğer & $657-99,8$ & $0-0$ & $0-0$ & $0-0$ & $1-0,2$ & 1,01 \\
\hline
\end{tabular}

Özel spor merkezi üyelerinin spordan beklentileri ile demografik özellikleri arasındaki ilişkinin dağılımı Tablo 4'de belirtilmiştir.

Tablo 4- Özel spor merkezi üyelerinin spordan beklentileri ve demografik özellikleri arasındaki ilişki (Anlamlılık Düzeyleri $(p)$

\begin{tabular}{|c|c|c|c|c|c|c|}
\hline $\begin{array}{l}\text { Demografik özellikler } \\
\text { Beklenti düzeyleri }\end{array}$ & $\begin{array}{l}\text { Cinsiyet } \\
\text { (p) }\end{array}$ & $\begin{array}{l}\text { Yaş } \\
\text { (p) }\end{array}$ & $\begin{array}{l}\text { Eğitim } \\
\text { düzeyi } \\
\text { (p) }\end{array}$ & $\begin{array}{l}\text { Meslek } \\
\text { (p) }\end{array}$ & $\begin{array}{c}\text { Gelir } \\
\text { düzeyi } \\
\text { (p) }\end{array}$ & $\begin{array}{l}\text { Üyelik } \\
\text { Süresi } \\
\text { (p) }\end{array}$ \\
\hline Hareket etmek & ,221 &, $000^{*}$ &, $002^{*}$ & ,715 &, 059 &, 061 \\
\hline Sağlıklı olmak & ,119 &, $000^{*}$ &, $000^{*}$ & ,167 & 441 & 321 \\
\hline Formda kalmak & ,990 &, $000^{*}$ &, $000^{*}$ & 307 & , 163 & 071 \\
\hline Zayıflamak & , 140 &, $000^{*}$ &, $002^{*}$ & 080 & 655 & ,578 \\
\hline Yeni insanlar tanımak & , 143 &, $004^{*}$ &, $000^{*}$ & 256 & ,367 & 674 \\
\hline $\begin{array}{l}\text { Serbest zamanı } \\
\text { değerlendirmek }\end{array}$ & ,561 &, $007^{*}$ & $000^{*}$ & 310 & 447 & 313 \\
\hline Stres atmak & 413 &, $005^{*}$ &, $000^{*}$ & , 140 & 154 &, 590 \\
\hline $\begin{array}{l}\text { Benlik } \\
\text { duygusunu geliştirmek }\end{array}$ & 219 &, $000^{*}$ &, $000^{*}$ & 654 & 289 & 446 \\
\hline Öz saygı kazanmak & ,544 &, $000^{*}$ &, $000^{*}$ & ,756 & , 185 & ,088 \\
\hline $\begin{array}{l}\text { Yeni deneyimler } \\
\text { kazanmak }\end{array}$ & 456 &, $001^{*}$ &, $000^{*}$ & ,536 & 099 & 498 \\
\hline Diğer & 245 &, $000^{*}$ &, $000^{*}$ & ,986 & 897 & ,987 \\
\hline
\end{tabular}


Tablo 4'den de görüleceği üzere yaş ve eğitim düzeyleri faktörleri dışında katılımcıların spordan beklentileri arasında anlamlı bir fark yoktur. Bireylerin yaşları ve eğitim düzeyleri arttıkça yaptıkları spor branşından beklentilerinin de arttığı söylenebilir. Bireylerin spordan beklentilerini belirlemek amaciyla sorulan sorulara verilen cevaplarda cinsiyet, meslek grubu, gelir düzeyi ve üyelik süresi bakımından anlamlı farklara rastlanmamıştır. Bu durum bireylerin sorular yakın cevaplar vermelerinden kaynaklanmaktadır.

Özel spor merkezi üyelerinin spordan beklentilerinin gerçekleşme düzeyleri arasındaki ilişki düzeyleri Tablo 5'de belirtilmiştir.

Tablo 5- Özel Spor merkezi Üyelerin Spordan Beklentilerinin Gerçekleşme Düzeyleri Arasındaki İlişki Düzeyleri

\begin{tabular}{|c|c|c|c|c|c|c|c|}
\hline \multirow{2}{*}{$\begin{array}{l}\text { Spordan } \quad \text { Beklenti } \\
\text { düzeyleri } \\
\text { geklenti } \\
\text { gerekleşme } \\
\text { düzeyleri }\end{array}$} & Hiç & $\mathbf{A z}$ & Orta & Çok & Tam & \multirow{2}{*}{$\mathbf{X}^{2}$} & \multirow{2}{*}{$\mathbf{P}$} \\
\hline & $\%$ & $\%$ & $\%$ & $\%$ & $\%$ & & \\
\hline Hareket etmek & $338-51,3$ & $225-34,1$ & $77-11,7$ & $18-2,7$ & $0-0$ & 130,4 & $0,00^{*}$ \\
\hline Sağlıklı olmak & $393-59,7$ & $170-25,8$ & $82-12,4$ & $4-0,6$ & $9-1,3$ & 93,5 & $0,00^{*}$ \\
\hline Formda kalmak & $345-2,4$ & $184-27,9$ & $111-16,8$ & $12-1,8$ & $6-0,9$ & 17,8 & $0,00^{*}$ \\
\hline Zayıflamak & $296-44,9$ & $153-23,2$ & $142-21,5$ & $41-6,2$ & $26-3,9$ & 32,3 & $0,00^{*}$ \\
\hline Yeni insanlar tanımak & $10-1,5$ & $87-13,2$ & $130-19,7$ & $276-1,9$ & $155-23,5$ & 0,49 & 0,82 \\
\hline $\begin{array}{l}\text { Serbest zamanı } \\
\text { değerlendirmek }\end{array}$ & $177-26,9$ & $154-23,4$ & $143-21,7$ & $126-19,1$ & $58-8,8$ & 23,3 & $0,00^{*}$ \\
\hline Stres atmak & $221-33,5$ & $210-31,9$ & $78-11,8$ & $82-12,4$ & $67-10,1$ & 38,2 & $0,00^{*}$ \\
\hline $\begin{array}{l}\text { Benlik duygusunu } \\
\text { geliştirmek }\end{array}$ & $280-42,5$ & $219-33,2$ & $106-16,1$ & $37-5,6$ & $16-2,4$ & 24,5 & $0,00^{*}$ \\
\hline Öz saygı kazanmak & $22-3,3$ & $40-6,0$ & $132-20,0$ & $212-32,2$ & $252-28,3$ & 0,0 & 0,94 \\
\hline $\begin{array}{l}\text { Yeni deneyimler } \\
\text { kazanmak }\end{array}$ & $203-30,8$ & $139-21,1$ & $105-15,9$ & $183-27,8$ & $28-4,2$ & 17,7 & $0,00^{*}$ \\
\hline
\end{tabular}

${ }^{*} p<0.05$

Tablo 5'da görüleceği üzere $\mathrm{p}$ değeri anlamlılık düzeyi olan 0,05 değerinden küçük olduğu için spor salonu üyelerinin hareket etmek, sağlıklı olmak, formda kalmak, zayıflamak, serbest zamanı değerlendirmek, stres atmak, benlik duygusunu geliştirmek ve yeni deneyimler kazanmak beklentileriyle spor branşından elde ettikleri sonuçların aynı olmadığı görülmüştür. Bu sonuca göre özel spor merkezi üyelerinin yukarıda belirtilen beklentilerin karşılanmadığı anlaşılmaktadır. 


\section{Tartışma}

Demografik faktörler arasında yer alan, yaş, cinsiyet, eğitim vb. özelliklerin, spora yönelmede etkili olduğu gözlenirken, sosyo-ekonomik ve kültürel yapılarının da destekleyici rol oynadığı gözlemlenmiştir. Yurt içinde ve Dünya çapında yapılan çok sayıda bilimsel çalışma, yaş, cinsiyet ve eğitimin bireyin düzenli spora katılımında etken olduğunu göstermektedir (Eyler, 2003; Loland,2004).

Katılımcılarının cinsiyete göre dağılımında, kadın bireylerin ağırlıkta olduğu görülmektedir (Tablo 1). Yapılan çalışmalarda da 20-30 yaş arasındaki kadınların, daha ileri yaş grubundaki kadınlara kıyasla daha fazla oranda spora katıldıkları gözlemlenmiştir (Yıldıran, Yetim ve Şenel,1996; Eyler,2003). Çalışma sonuçlarının, geçmiş çalışma sonuçlarıyla paralellik gösterdiği söylenebilir. Zira tüm üyelik süreleri içerisinde en yüksek seviyede olan yaş grubu 26-40 yaş grubudur (Tablo 1) Çalışma sonuçlarının Gordon ve arkadaşlarının Houston'da 1441 kişiye uyguladıkları çalışmanın sonuçları ile paralellik gösterdiği, Gordon'un çalışmasında da bireylerin yaşları yükseldikçe sportif faaliyetlerden çekilmenin artmakta olduğu tespit edilmiştir (Gordon ve Scott,1976).

Üyelik süresini cinsiyetlerine göre inceleyecek olursak 6 yıldan fazla üyelik süresinde erkek üyeler çoğunluğa sahipken, diğer tüm sürelerde kadın üyeler çoğunluktadır (Tablo 1). Buradan, üyelik süresi arttıkça erkek üyelerin kadın üyelere oranla spora katılımlarının daha fazla olduğu söylenebilir Kadınlarda spor yapma oranındaki görülen azalmanın nedeni olarak; evlilik hayatının getirmiş olduğu sorumluluklar ve uzun yıllar spor yapma bilincinin erkeklere nazaran yeterince oluşmamış olması gösterilebilir.

Gelir düzeyi dağılımı ile spora yönelme oranları arasında yüzdesel olarak büyük bir farklılık görülmemektedir. Mamak'ın 2000 yılında yaptığ1 araştırmada ekonomik durum iyi düzeyde olan ailelerin çocuklarının spora katılımın fazla olduğunu tespit etmiştir. (Mamak, 2000). Nazik'in bu konuda yaptığı diğer bir araştırmaya göre ise bireylerin kazanç seviyelerinin yüksek olması, sporun yanı sıra bir çok sosyal aktiviteden daha çok yararlanmalarına olanak sağlayacağı yönündedir (Nazik, 1998). Bu bulgular, çalışma bulgularıyla zıtlık göstermiştir. Nitekim üye dağılımlarına bakacak olursak üyelerin ağırlıklı olarak 
ortalama gelir düzeyleri 1000-2500 TL aralığındadır. Ayrıca yapılan analizlerde de gelir düzeyi ile spora katılım arasında anlamlı bir fark bulunamamıştır. Çamlıyer'in 1992 yılında yaptığı bir araştırmada, deneklerin meslek dağılımları çok çeşitli olmasına karşın eğitim düzeylerinin Lise ve Üniversite olması spor yapma ile eğitimin yakından ilgili olduğunu ortaya koymuş bu sonuç ve araştırma bulgularıyla paralellik göstermiştir (Çamlıyer, 1992). Erkal'a göre ise eğitim seviyesinin yükselmesi spor talebini olumlu yönde etkileyen faktörler arasında sayılabilir. Diğer bir ifadeyle eğitim düzeyi yüksek olan kişilerin spora aktif olarak katılma istek ve arzusu, eğitim seviyesi düşük olanlara göre daha fazladır (Erkal,1993). Çamlıyer ve Erkal'ın bulguları çalışma bulgularıyla paralellik göstermektedir. Eğitim durumuna göre spora yönelme oranlarına bakıldığında, olarak eğitim düzeyi arttıkça spor yapanların oranının da arttığı söylenebilir.

Meslek gruplarına göre bireylerin spora yönelme oranlarına bakıldığında, bireylerin çoğunlukla serbest mesleklerde çalıştıkları ve emekli oldukları görülmektedir. Serbest meslek grupları ile Bireylerin emekli olduktan sonra spora daha fazla vakit ayırabildikleri sonucu çıkarılabilir. Bireylerin üyelik sürelerine göre spora yönelme oranları ise üyelerin \%39, 6 sinın 1 yıldan az, \%34 ü 1-3 yıl arasında, üyelik süresine sahip olduğu görülmektedir. Buradan da, üyelerin spor yapma bilinçlerinin yeni yeni oluşmakta olduğu söylenebilir.

Özel spor merkezi üyelerini spora yönelten etmenler ise; okul, işyeri, aile, doktor önerisi, basın-yayın ve diğer faktörlerin bireylerin büyük çoğunluğunun üzerinde etkili olmadığı, bunların yerine bireylerin arkadaş ve ikametgah yeri faktörlerinin daha etkili oldukları söylenebilir. Kenyon ve Grogg tarafından yapılan araştırmaya göre aile, bireylerin boş zaman tercihlerinin en önemli belirleyici unsurlarından biridir ve bireylerin spora yönelmelerinde aile en etkin olan unsurdur (Kenyon ve Groog,1970). Buna karşın bu sonuç araştırma sonuçları ile paralellik göstermemektedir. Araştırmaya katılan bireylerin spora yönelten nedenlere ilişkin sorulara verdikleri cevaplara bakıldığında, bireylerin spora yönelmelerinde \% 35,9 oranıyla arkadaş faktörünün ve \%31,0 oranıla ikametgah yeri faktörünün ağırlıklı olarak etkili olduğu gözlemlenmektedir. Eroğlu'nun İstanbul'da spor merkezlerinde üyelik yenilemelerini etkileyen faktörler üzerine yapmış olduğu çalışmada 
araştırmaya katılan bireylerin büyük çoğunluğunun spor yaptıkları tesisi tavsiye ettikleri sonucuna ulaşılmıştır. Aynı zamanda düzenli olarak spora katılım ile spor merkezinin eve veya işyerine uzak olması ilişkisini de ele alan Eroğlu, düzenli olarak spor yapmayanların spor merkezine gelişe etkili olan spor merkezinin eve ve işyerine uzak olması probleminden dolayı düzenli olarak spor yapanlara göre daha fazla etkilendikleri sonucuna ulaşmıştır (Eroğlu, 2006). Özdilek ve Kılıç'ın 2006 yılında yaptıkları çalışmanın bulgulardan da anlaşılıyor ki, bu çalışmaya katılan 1067 katılımcıdan 497 tanesi spor komplekslerinin uzakta olması spor yapmaya olumsuz olarak etki ettiği belirtilmiştir. Araştırmaya katılanların sadece 167 tanesi ise spor komplekslerinin uzaklıkta olmasının spor yapmaya olumsuz etkisinin olmayacağını belirtmiştir (Özdilek ve Kılıç, 2006). Bu iki çalışmanın sonuçlarına göre çalışma ile benzer sonuca ulaşılmıştır denebilir. Buna göre, spor merkezlerinin trafik probleminin fazlaca yaşanmayacağı, herkes için kolay ulaşılabilecek bir yerde olması büyük önem arz etmektedir.

Çalışmanın amacı doğrultusunda katılımcıların spordan beklentileri ve bu beklentilerin gerçekleşme düzeylerini belirlemek amacıyla hazırlanmış 22 soruya verilen cevaplar ile, bireylerin spordan beklentilerinin karşılanma düzeyleri araştırılmıştır. Araştırmaya verilen cevaplar doğrultusunda özel spor merkezlerine üye olan bireylerin spordan beklentileri sırasıyla; Formda kalmak, Hareket etmiş olmak, Zayıflamak, Sağlıklı Olmak, Öz Saygının artması, Boş Zamanları Değerlendirmek, İşten, Okuldan sonra stres atmak, Benlik Duygusunu Geliştirmek, Yeni deneyimler kazanmak, Diğer beklentiler şeklindedir. Bireylerin özel spor merkezlerine gelmekteki amaçlarına bakıldığında \%64,1 oranla formda kalmak için spor salonuna gelmek istediklerini ifade ettikleri görülmektedir. Hareket etmiş olmak için diyenlerin oranı ise yaklaşık \% 59,4 civarındadır. \%51,4 oranında zayıflamak için spor salonlarına geldikleri görülmektedir.

Sağlıklı olmak için özel spor merkezlerine gelen bireylerin oranı \%49,5 iken, öz saygıyı arttırmak için gelen üyelerin oranı \%38.1' dir. Boş zaman değerlendirilmesi ve iş, okul sonrası stres atımı için özel spor merkezlerine gelen üyelerin oranları sırasıyla $\% 40,6$ ve $\% 39,2$ iken, benlik duygusunu geliştirmek için gelen üyelerin oranı $\% 38,1$ ve yeni deneyimler kazanmanın oranı ise \%33,3 tür (Tablo 3). Güdül'ün 2008 yılında yapmış olduğu bir araştırmanın sonuçlarına göre, araştırmaya konu olan 
özel spor merkezi üyelerinin spor merkezlerine gelmekteki amaçlarına bakıldığında \% 50 oranında sağlıklı olmak için spor merkezine gelmek istediklerini ifade ettikleri görülmektedir. Stres atmak ve kilo vermek için diyenlerin oranı ise yaklaşık \% 45 civarındadır. "Doktorum önerdiğ $i$ için geliyorum" diyenlerin oranı \% 15 iken, bireylerin \% 28'inin boş zamanlarını değerlendirmek için spor merkezlerine geldikleri görülmektedir. Araştırma sonucunda bireylerin kilo vermek, spor yapmak, vakit geçirmek ve vücut geliştirmek için özel spor merkezlerine geldikleri belirtilmektedir. Bu bulgular çalışma bulguları ile paralellik göstermektedir (Güdül, 2008). Sağlıklı olmak ve sağlıklı kalmak insanların en temel amaç ve hedeflerinden birisini oluşturmaktadır. Spor yapan insan sağlıklı bir beden formuna sahip olduğunu düşünmekte ve huzurlu olabilmektedir. Spor etkinliklerine katılanların tamamına yakını spor yapmanın iş stresi ve günlük streslerle başa çıkmada yardımcı olduğunu ve sağlı̆̆ı açısından olumlu etki yaptığını belirtmişlerdir. Burada düzenli olarak yapsin ya da yapmasin sporun faydaları konusunda hemfikir olmuşlardır. Yapılan diğer araştırmalarda da fiziksel aktivitelere katılan bireyler kendilerini daha mutlu, daha özgür hissettiklerini ve böylece gündelik çalışma hayatlarında yaptıkları işlerin verimini arttığını belirtmektedirler (Demirhan, 2003; Tel ve Köksalan, 2008). Bıyıklı'nın 2007 yılında yapmış

olduğu araştırma da genel olarak anket katılımcılarının egzersize başlama nedeni olarak çok büyük oranda fiziksel ve ruhsal olarak sağlıklı kalmak, kilo vermek ve fiziksel performansı artırmak olarak ortaya çıkmaktadır (Bıyıklı, 2007). Araştırmaya konu olan bireylerin spordan beklentilerinin gerçekleşme düzeylerini içeren anket sorularına vermiş oldukları cevaplara istinaden bireylerin, sağlıklı olma, hareket etmiş olma, form koruma, zayıflama, boş zamanlarını değerlendirme, stres atma, benlik duygusunu geliştirme ve yeni deneyimler kazanma beklentileri tam anlamıyla karşılanmamış olmakla beraber bireylerin yeni insanlar tanıma ve öz saygı kazanma beklenti düzeylerinin büyük ölçüde karşılandığı söylenebilir. Özel spor merkezlerine üye olan bireylerin yaptıkları spor branşından beklentilerinin gerçekleşme oranlarının artırılmasında bu spor merkezlerinin mevcut üyelerine yönelik hizmet, tutum ve davranışlarının rol oynadığı gerçeğini göz önünde bulundurarak özel spor merkezlerindeki hizmet kalitesi artırılarak bireylerin 
beklentilerine daha çok cevap verilebilmesi ve bireylerin özel spor merkezlerinde geçirdikleri zamanın artırılması ile geniş kitlelerin yoğun ilgisini çeken bir sağlık ve eğlence faaliyeti olarak tüketim sektörüne dönüştürülebilir.

\section{Sonuç ve Öneriler}

Özel spor merkezlerine giden bireylerin beklentilerinin belirlenmesine yönelik yapılan bu araştırmada, ankete katılanların spor merkezlerine gelmekteki amaçlarının; Stres atmak, Kilo vermek ve Sağlıklı olmak olduğu sonucuna ulaşılmıştır. Bu amaçların ise; Yaş gruplarında, Cinsiyette ve Sosyo-ekonomik durum özelliklerinde benzerlikler taşıdığı ortaya konmuştur.

Çalışmanın sonucunda sahip olunan sosyo-ekonomik yapının, spora katılım düzeylerini etkilediği görülmüştür. Bu etkileme; iyi imkânların sporu teşvik edici faktör veya kötü imkânların kısıtlayıcı faktör olarak gösterilemeyeceği şeklindedir. Uç noktalarda spor yapan kesimin az bulunduğu, spor yapan kesimin ortanın üzerinde ve altında toplandığ 1 tespit edilmiştir. Bireylerin özel spor merkezlerine yönelmelerinde en etkili faktörlerin; Arkadaş faktörü ve İkametgah faktörü olduğu görülmüştür. Özel spor merkezlerine üye olan bireylerin, bu merkezlere öncelikli olarak "Sağlıklı olmak", "Hareket etmek", "Formda kalmak", "Stres atmak" ve "Zayıflamak" beklentileriyle üye oldukları ancak bu beklentilerinin karşılanmadığı ancak Yeni insanlar tanımak ve Öz saygı kazanmak beklentilerinin karşılandığ 1 görülmüştür. Araştırmaya konu olan spor tesislerinin büyük bir çoğunluğu çok amaçlı olarak işletilmekte ve fitness, step, aerobik, pilates, yoga, spinning, squash, yüzme, tenis vb. alanlarda faaliyet göstermektedirler.

\section{Öneriler;}

Önemli bir fonksiyonu yerine getirmeye çalışan spor merkezlerinin, bu merkezlere devam eden bireylerin beklentilerine ne ölçüde cevap verebildiğinin belirlenmesi oldukça önemlidir. Dolayısıyla üyelerin spora yönelmelerindeki birincil etkenler spor eğitmenleri tarafından tespit edilerek bu beklentiler doğrultusunda antrenman programları hazırlan- 
abilir. Ancak bu programların sık sık yenilenerek program etkinliğinin artırılması sağlanmalı ve üyelerin spor yapma amaçlarının ve beklentilerinin ne ölçüde gerçekleştiği takip edilmelidir. Üyelerin karşılanamayan beklentileri ile ilgili olarak bireylerin sosyolojik ve psikolojik özelliklerini de içeren çalışmalara yer verilerek toplumun spora yönelmesi ve spordan beklentilerinin karşılanma düzeylerinin artırılması bireylerin spor etkinliklerine katılmalarını arttırmada önem arz edecektir. Buna gore, spor merkezlerine üye bireylerin bu merkezlere düzenli devam etmelerini sağlayacak hareket etmeyi özendirici nitelikte spor organizasyonları ya da etkinlikleri düzenlenmeli ve bu etkinliklerde başarılı sonuçlar alanlar ödüllendirilmelidir. Ayrıca, sağlıklı olmak, formda kalmak, zayıflamak gibi beklentilerin karşılanmasına yönelik olarak spor merkezlerinde beslenme ve diyet uzmanının bulundurulması ya da istihdam edilmesi sağlanmalı ve üyelerin sağlık verileri sürekli kontrol edilmelidir. 
EXTENDED ABSTRACT

\title{
Reasons and Satisfaction Rate of Expectations of the Individuals Who Are Members of Private Sport Centers
}

\author{
Nevzan Şelale Akça - Hakan Sunay \\ Ankara University
}

Today, sports and human life have become inseparable. Therefore, regardless of age, scientific-based, conscious and systematic sport plays an important role in keeping healthy, harmonious, successful, happy and normal power throughout human life. (Amman, 2005) The main purpose of sports; to prevent or slow down organic, psychological and physical disorders caused by a sedentary life, is to increase the physiological capacity, which is the basis of body health, and to maintain physical fitness and health for many years. Article 59 of the 1982 Constitution act states that the provision of physical education for citizens of all ages is the duty of the state. For this reason, with the mottos like "Mass Sports", "Lifelong Sports", "Sports for everybody" and "Sports for healthy life", the tendencies of these individuals to engage sports in leisure activities have been encouraged in order to actively engage individuals of different genders, occupations and status. (Fişek, 1998) Today, sports are considered as an important service sector with the qualities protecting and improving personal and social health. Therefore, the importance given to sports activities and organizations is increasing.

The aim of this study is to investigate the reasons of the individuals who are members of special sports centers in Ankara, taking into consideration the importance of sports to create a contemporary society in a healthy, social and cultural area.

According to data of the General Directorate of Sports (SGM) in Ankara, there are 33 small and large body building and fitness centers. Target population of the study is located in 15 private sports centers having bodybuilding halls as well as various sports branches with more than 500 members in Ankara, in 2014. The universe of the research; It is com- 
posed of approximately 24,500 people who are members of 15 private sports centers. The research sample consisted of 658 people who participated in these centers and volunteered to participate in the research. A questionnaire was used as a data collection tool. The questionnaire consists of 36 questions aimed at determination of personal information and expectations. In section 1 of the questionnaire, demographic factors such as age, gender, education status, occupations and income levels of individuals using sports facility were prepared by using a 5 point Likert scale in section 2 with 30 questions in total. The aim of this section is to determine the factors that affect the tendency of the individuals to sports using the sports center, the expectations from the sports and the level of realization of these expectations. For the analysis of the collected data, the chi-square analysis was performed for the frequency and percentage (\%) distributions, and the alpha value for the statistical significance was accepted as 0.05 . The Cronbach's Alpha value $(\alpha)$ for the 30-questions section prepared with a 5-point Likert scale was 74.6. The data were analyzed by Kaiser-Meyer-Olkin (KMO) coefficient and Barlett Sphericity test for descriptive factor analysis. KMO value (.838); shows that the sample size of 658 in this example is sufficient and in the results of Bartlett Bars test $(\mathrm{p}<.01)$ the data are in normal distribution: KMO's higher than .60 , and the significant Barlett test indicates that the data are suitable for factor analysis. (Büyüköztürk, 2018) Analysis result; the items in the scale are collected in one factor and the factor loadings of the items vary between $75-57$. The item total correlations also indicate that the substances have high discriminative powers. The item total correlations ranged from 72 to 52 . Accordingly, it can be said that each item of scale has a high level of distinctiveness. 30 items whose item-total correlations coefficient is higher than 0.52 were included in the scale.

According to the results obtained from the analysis, the factors that led to the sports were $73.9 \%$ (486 people) of the individual's wish, 38.9\% ( 256 people) of the family effect, $63.1 \%$ (415 people) of the school factor, $64 \% 9$ percent (427 people) of the workplace factor and 41.5 percent of (273 persons) were determined to "have no effect" among the factors leading to sports. On the other hand, $35.9 \%$ (236 people) of the friendship factor and the proximity to sports centers $(31.0 \%-204)$ effect level have been seen as high. Expectations of the members of the special sports cen- 
ter from the sports branches; moving, being on form, blowing off steam and losing weight are at the high level of expectation, while meeting new people, improving sense of self, increasing self-esteem and gaining new experiences are at the low level of expectation. There is no significant difference between the expectations of the participants from the sport except for the age and education level factors of the individuals. According to this, it can be said that the expectations from the sports branches increased as individuals' ages and education levels increased.

As a result, the objectives of the individuals to come to sports centers; it was concluded that it was to blow off steam, to lose weight and to be healthy. It was determined that the socio-economic structure had an influence on the level of participation in the sports. The most influential factors in the orientation of individuals to private sports centers were found as friendship factor and residence factor. It has been determined that the individuals who are members of the private sports centers are members of these centers with the primary purpose of being Healthy, Moving, Being Fit, Blowing off steam and Losing weight, but these expectations are not met, only meeting new people and self-esteem expectations are met. Regarding the unfulfilled expectations of the members, it will be important in increasing the participation of individuals in sports activities to increase community orientation to sports and increase the level of meeting expectations from sports with the studies including sociological and psychological characteristics of individuals.

\section{Kaynakça / References}

Amman, M.T. (2005). Kadın ve spor, içinde (64-89), İstanbul: Morpa Kültür Yayınları.

Balcı, A.(2015). Sosyal bilimlerde araştırma yöntem teknik ve ilkeler, (11.Bsm), Ankara: Pegem Akademi Yayıncllık.

Bıyıklı, T. (2007). Vücut imgesinin ve özel spor salonlarını egzersize başlama ve devam etme motivasyonu üzerine etkisi.Yüksek Lisans Tezi, Gazi Üniversitesi Sağlık Bilimleri Enstitüsü Beden Eğitimi ve Spor Anabilim Dalı, Ankara.

Brown, B. andFrankel. B.G. (1993). Activity through the years, leisure, leisure satisfaction and life satisfaction. Sociology of Sports Journal, 10,1-7. 
Büyüköztürk, Ş.(2018).Sosyal bilimler için veri analizi el kitabı istatistik, araştırma deseni, SPSS uygulamaları ve yorum, (24.Bsm), Ankara:Pegem Akademi Yayıncilik.

Çamlıyer, H. (1992). Orta yaş kadınlarda aerobik jimnastik çalışmalarının psiko-sosyal boyutları. Bildiriler, içinde (212-220), II. Uluslararası Spor Bilimleri Kongresi. Hacettepe Üniversitesi,1992, Ankara.

Demirhan , G. (2003). Kültür, eğitim, felsefe ve spor eğitimi ilişkisi. Spor Bilimleri Dergisi, 14, 92-103.

Erkal, M. (1993). Sosyolojik açıdan spor, içinde (86-90), İstanbul: Kutsun Matbaa ve Reklamcilık Merkezi.

Eroğlu, E. (2006). Spor merkezlerinde üyelik yöntemlerini etkileyen faktörlerin araştırılması. Yüksek Lisans Tezi, Marmara Üniversitesi Sağlık Bilimleri Enstitüsü Beden Eğitimi ve Spor Anabilim Dal, İstanbul.

Eyler, A. (2003). Personal, social and environmental correlates of physical activity in rural midwestern white women, American Journal of Preventive Medicine, 25, 86-92.

Fişek, K.,(1998). Devlet Politikası ve Toplumsal Yapıyla İlişkileri Bakımından Dünya'da ve Türkiye'de Spor Yönetimi, (2.Bsm), Ankara:Bağırgan Yayınevi,

Gordon, C.G. and Scott, J. (1976).In Leisure and Lives: Personel Expressivity Across The Lifespan in Handbook of Aging and The Social Sciences, (310-341),New York: Van Nostrand Reinhold Co.

Güdül, N. (2008). Fitness salonlarna giden bireylerin beklentileri:Bursa ili örneği, Yüksek Lisans Tezi, Afyonkarahisar Kocatepe Üniversitesi Sağlık Bilimleri Enstitüsü Beden Eğitimi ve Spor Anabilim Dalı. Afyon.

Kaptan, S., (1998). Bilimsel araştırma teknikleri, 11. Baskı, Ankara:Bilim Yayıncilik.

Kenyon, G.S. and Grogg, T.M. (1970). Contemporary psychology of sport. International Society of Sport Psychology. Chicago:Athletic Institute.

Loland, N. W. (2004). Exercise, health and aging. Journal of Aging and Physical Activity, 11, 170-184. 
Mamak, H. (2000). Zonguldak'ta spora katılımın sosyo-ekonomik boyutu:Orta öğretim gençliği üzerine bir araştırma. Yüksek lisans Tezi, Gazi Üniversitesi Sağlık Bilimleri Enstitüsü Beden Eğitimi ve Spor Anabilim Dall, Zonguldak.

Nazik, M. H. (1998). Aile ve bireylerin hayat seviyeleri ve bunu etkileyen faktörler. Türkiye Sosyal Araştırmalar Dergisi, 2, 55-56.

Özdilek, Ç. ve Kılıç, K. (2006). Harcanabilir gelirin artmasının sportif rekreasyona katılıma olan etkisinin araştırılması:İstanbul örneği. Yüksek Lisans Tezi, Dumlupınar Üniversitesi Sosyal Bilimler Enstitüsü Beden Eğitimi ve Spor Anabilim Dalı,İstanbul.

Tel, M. ve Köksalan, B. (2008). Öğretim üyelerinin spor etkinliklerinin sosyolojik olarak incelenmesi:Doğu Anadolu örneği. Fırat Üniversitesi Sosyal Bilimler Dergisi, 1, 261-278.

Yıldıran, İ., Yetim, A. ve Şenel, Ö. (1996). Farklı cinsiyetteki lise öğrencilerinin beden eğitimi dersinden beklentileri. Gazi Beden Eğitimi ve Spor Bilimleri Dergisi, 1, 52-57.

\section{Kaynakça Bilgisi / Citation Information}

Akça, Ş. N. ve Sunay, H. (2019). Özel spor merkezlerine üye olan bireylerin spora yönelme nedenleri ve beklentileriningerçekleşme düzeyleri. OPUS-Uluslararası Toplum Araştırmaları Dergisi, 11(18), 1474-1493. DOI: 10.26466/opus.549924 